\title{
RANCANG BANGUN WAS (Weather Automatic Station) PENDETEKSI CUACA SECARA REAL TIME DAN TERINTEGRASI GUNA MENDUKUNG KESELAMATAN PELAYARAN KAPAL RAKYAT DI MALUKU
}

\author{
Jacob D. C. Sihasale ${ }^{1}$, Sonya. T.A. Lekatompessy \\ E-mail: 1yb8xm2010@gmail.com \\ Fakultas Teknik Universitas Pattimura
}

\begin{abstract}
ABSTRAK
Kebutuhan data real time Cuaca di daerah pelayaran sangat di butuhkan, ini demi keamanan dan keselamatan sebuah pelayaran. Penyedia data real time di daerah pelayaran khususnya di daerah maluku tengah dapat dikatakan tidak tersedia dan tidak dapat diakses secara on line oleh pelaku pelayaran maupun para calon penumpang sebuah pelayaran di Maluku Tengah.

Kehadiran data WAS ( Weather Automatic Station) secara real time dan akurasinya dibutuhkan dalam sistim pelayaran dan manejeman transportasi laut, juga di butuhkan dalam dunia pendidikan guna berbagai ke butuhan penelitian lainnya. Ketersediaan WAS yang terbatas merupakan tantangan yang perlu dicari solusinya.

Keamanan sebuah Pelayaran membutuhkan data cuaca yang tepat dan akurat, ini sangat tergantung dari ketersedianya data WAS ( Weather Automatic Station) yang berada dekat dengan lokasi pelayaran. Data yang di peroleh dapat di akses dari berbagai media secara cepat dan tepat oleh penyedia pelayaran, calon penumpamg pengawas dan regulator pelayaran serta berbagai pihak yang berhubungan dengan pelayaran.

Penelitian ini merupakan penelitian lanjutan untuk mendapatkan data real time Cuaca daerah pelayaran Maluku Tengah melalui WAS yang di bangun di Pulau saparua, WAS Tulehu kemudian ditambah dengan WAS Wipirit dan WAS Liang.

Data yang diterima Sensor paremeter cuaca WAS kemudian di kirim melalui radio VHF ke station Penerima yang berlokasi di Kampus Fakultas Teknik Unpatti Ambon, yang kemudian diolah dan didistirbusikan ke berbagai media dan di simpan guna kepentingan penelitian lainnya.

Dari data yang di dapat diharapkan pengetahuan para pelaku pelayaran serta calon penumpang akan kondisi cuaca sesaat dapat merekomendasikan keamanan dan kenyamanan sebuah pelayaran.
\end{abstract}

Kata Kunci: WAS ( Weather Automatik Station), Sensor, Radio, Keamanan

\section{PENDAHULUAN}

Maluku merupakan salah satu propinsi yang wilayahnya terdiri dari $658.295 \mathrm{Km}^{2}$ perairan lebih besar dari luas daratan yang hanya 47.351 $\mathrm{Km}^{2}$, ini meyebabkan transportasi laut memegang peranan penting di daerah ini.

Dalam operasional transportasi laut apa pun bentuknya baik Kapal, Kapal Fery, Kapal Cepat, Speed Boat, sampai pada perahu nelayan. Sarana transprtasi ini akan berfungsi dengan baik jika keseluruhan factor pendukung yaitu manusia, alam serta kondisi alat ransportasi berada pada kondisi baik

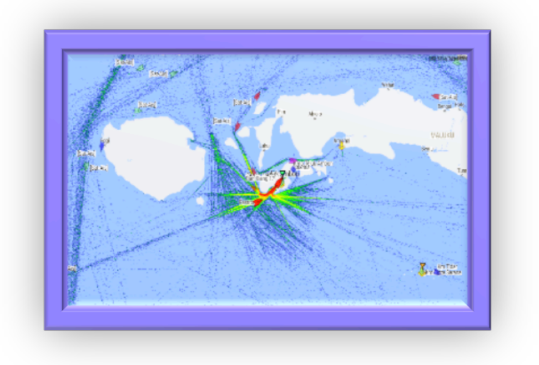

Kepadatan transportasi laut Maluku Tengah
Kegagalan transportasi laut dapat terjadi karena beberapa masalah antara lain :

1. Kesalahan Manusia.

2. Kegagalan Tekink / alat transportasi

3. Kondisi Alam Bersahabat.

Masalah Kegagalan transportasi laut menyebabkan kegagalan pelayaran untuk sampai di tujuan yang di rencankan. lebih dari itu kegagalan transportasi laut dapat berakibat pada terjadinya korban Manusia dan Harta benda ( Data kecelakaan Laut Terlampir).

Kegagalan pelayaran laut yang diakibatkan karena kecelakaan di Indonesia pada umumnya dan di Maluku pada kususnya di sebabkan karena Kondisi Alam yang tiba- tiba berubah pada saat pelayaran dan kondisi manusia, baik manusia sebagai pemegang kendali dan manusia sebagai penumpang, baik pada kapal penumpang, kapal fery maupun pada speed boat yang beroperasi sebagai sarana transportasi penumpang antar pulau serta perahu nelayan sebagai sarana pencari ikan pada masyarakat menengah ke bawah. 
Kegagalan atau Kecelakaan yang di sebabkan karena factor alam yang berubah maka Manusia sebagai pemegang kandali pada sebuah kapal tidaklah dapat berbuat banyak, untuk itu dibutuhkan pengamatan awal kemungkinan perubahan cuaca alam pada lintasan perjalanan sebuah kapal.

Kecelakaan juga dapat terjadi akibat pemahaman atau penegetahuan manusia sebagai penumpang tidak memahami akan kondisi alam sehingga memaksakan diri untuk tetap berlayar, ini sering terjadi pada transportasi rakyat antar pulau.

Kondisi ini hanya dapat di minimalisir dengan pengetahuan tentang perubahan cuaca yang dapat diketahui, oleh manusia sebagai pengengedali transportasi dan manusia sebagai calon penumpang, untuk itu keberadaan peralatan pengukur navigasi, cuaca baik di pelabuahan, kantor kesahbandaran atau pun peralatan yang tersedia pada kapal - kapal besar, sementara pada kapal kecil dan transportasi rakyat serta kapal nelayan umumnya tidak tersedia.

Karena cuaca adalah kondisi alam pada kurun waktu yang pendek dan luas daerah yang tidak terlalu luas maka keberadaan station pengukuran cuaca sangatlah efektif jika berada pada radius 50 sampai $100 \mathrm{~km}$ satu sama yang lainnya.

Bagi masyarakat ilmiah dalam melakukan penelitian - penelitian yang berhubungan dengan cuaca kebutuhan data cuaca real time sangat di butuhkan.

Barawal dari kebutuhan akan data cuaca, khusus untuk transportasi rakyat dan kebutuhan data untuk masyarakat ilmiah dalam hal ini kampus serta kebutuhan mahasiswa untuk menyelesaikan penelitan dan tuagas akhir inilah peneliti berkeinginan melakukan penalitan guna dapat membangun beberapa staion pengukur cuaca yang terintegrasi guna menunjang kebutuhan diatas.

Penelitian ini akan di fokuskan pada pembangunan 4 buah station deteksi cuaca pada pelabuhan Haria Pulau saparua dan pelabuhan Tulehu, pelabuhan Liang di pulau Ambon, Pelabuhan Waipirit di pulau Seram dan 1 stasion penerima dan pengolah serta berfungsi sebagai server yang terletak di Kampus Fakultas Teknik Universitas Pattimura Ambon.

Dengan keberadaan 4 buah WAS (Weather Automatic Station) yang berfungsi sebagai pendeteksi dan dilengkapi dengan berbagai sensor cuaca yang kemudian di kirim dengan menggunakan radio ke station penerima dan di olah secara otomatis serta di sebarluaskan melalui jaringan internet yang tersedia pada Fakultas Teknik Ambon.

\section{PERUMUSAN MASALAH.}

Sehubungan dengan pentingnya Data cuaca yang akurat dan real time dalam Dunia pelayaran guna menjamin kenyamanan dan keselamatan pada sebuah pelayaran serta di dunia pendidikan guna penelitian lanjutan yang berhubungan dengan transportasi perkapalan maupun bidang lainya maka kehadiran WAS (Weather Automatic Station) sangatlah di butuhkan.

Dengan demikian kita dapat melihat kondisi cuaca saat itu pada kedua lokasi WAS ( Weather Automatic Statian) dan daerah sekelilingnya. Data tersebut dapat kita bagikan lewat berbagai media on line yang berhubungan dengan cuaca dan dapat diintegrasikan ke berbagai web. Selain itu data tersebut dapat kita simpan guna kebutuhan penelitian lanjutan di Station Penerima.

\section{Batasan Masalah :}

Pada Penelitian ini diberikan batasan :

1. Mendisain WAS Liang dan WAS Waipirit

2. Membangun station WAS Di Pulau Saparua, dan Pelabuhan Tulehu, Pelbuhan Liang dan Pelabuhan Waipirit

3. Membangun Station Penerima WAS di kampus Fakultas Teknik Universitas Pattimura Ambon.

4. Mengirim data yang terekam dari daerah 4 WAS yang di bangun ke Station penerima di kampus Fatek Unpati Ambon.

5. Membuat portal - portal ke web -web nasional maupun international yang berhubungan dengan Cuaca dan pelayaran serta di akses banyak orang.

\section{TUJUAN DAN MANFAAT PENULISAN}

Tujuan penelitian Tahap I ini adalah :

1. Membangun WAS di daerah pelabuhan Haria Pulau saparua.

2. Membangun WAS di daerah pelabuhan Tulehu Pulau Ambon.

3. Membangun Station Penerima data dari WAS di fakultas teknik Unpatti.

4. Uji coba penerimaan data dari kedua WAS.

Tujuan penelitian Tahap 2 adalah :

1. Membangun WAS Liang dan WAS Waipirit

2. Mengurangi Angka Kecelakaan Laut yang di akibatkan karena pengaruh cuaca. 
3. Mengurangi Angka korban Manusia yang diakibatkan karena kecelakaan laut yang disebebkan karena pengaruh cuaca

4. Memberikan layanan kepada masyarakat, pengelola kapal pelayaran, serta pelayaran rakyat akan data cuaca real time daerah pulau Ambon dan Maluku Tengah, khususnya pada lalu lintas pelayaran Tulehu Haria. yang dapat di akses murah dan mudah.

5. Khusus buat nelayan kecil dapat mengetahui Kondisi cuaca di sekitarnya dari HP yang dimilikinya.

6. Menjadikan kampus sebagai sumbar data yang dapat di pertanggung jawabkan dan di percaya.

Manfaat yang akan di dapat dengan adanya station cuaca dan pengembangannya yakni :

1. Pelayaran sebuah kapal, kapal rakyat speed boat dan nelayan akan lebih efektif.

2. Keselamatan Pelayaran menjadi lebih Aman.

3. Estimasi perjalanan lebih Akutrat.

4. Masyarakat tidak ragu untuk melakukan perjalanan.

5. Data yang tersimpan dapat di gunakan oleh para Peneliti, Mahasiswa, dan siapa saya yang membutuhkan guna menyelesaikan kebutuhan persoalan cuaca.

6. Akan menjadikan Kampus fakultas teknik, Laboratorium yang tersedia sebagai pusat data safety dan navigasi Propinsi Maluku.

\section{KAJIAN TEORI DAN METODE}

\section{Gambaran Umum dan cara kerja WAS.}

Cuaca dan iklim adalah dua istilah yang berkaitan dengan Lapisan Atmosfir, Perbedana keduanya terletak pada waktu dan wilayah trejadinya.

Cuaca adalah keadaan Udara pada suatu saat di tempat tertentu. Keadaan cuaca senantiasa berubah ubah dari waktu ke waktu. Cuaca merupakan keadaan Atmosfir sehari hari yang dapat terjadi dan berubah dalam waktu yang singkat di daerah yang sempit.

Iklim adalah rata - rata kondisi tahunan dan meliputi wilayah yang luas.

Melihat dari difinisi cuaca diatas maka guna mengkaverr Maluku yang sangat luas maka di butuhkan sangat banyak stasiun cuaca, guna mengantisipasi keselamatan pelayaran di laut sebuah kapal.

Unsur - unsur yang mempengaruhi cuaca dan iklim adalah :
- Suhu Udara.

- Tekanan Udara..

- Angin.

- Kelembaban Udara.

- Awan.

- Curah Hujan.

\section{Cuaca dan pelayaran}

Informasi cuaca harian tidak hanya untuk penerbangan atau masyarakat tapi dapat juga dimanfaatkan untuk kegiatan pelayaran, seperti tinggi gelombang dan angin kencang yang terjadi di tengah laut. Bagi masyarakat yang sudah mengetahui informasi cuaca kelautan akan bermanfaat untuk merencanakan jadwal/waktu keberangkatan kapal laut, sehingga diharapkan terhindar dari cuaca buruk di laut. Informasi cuaca untuk Pelayaran adalah cuaca yang diperuntukan khusus untuk dunia pelayaran, baik untuk saat akan berlayar, berlabuh maupun selama pelayaran. Umumnya informasi unsur cuaca yang dibutuhkan untuk pelayaran adalah keadaan hujan, keadaan angin, jarak pandang, dan tinggi gelombang. Yang paling ditakuti bagi pelayaran adalah tinggi gelombang baik untuk jenis kapal nelayan maupun jenis kapal yang besar. Informasi cuaca yang diperlukan untuk pelayaran antara lain : intensitas hujan, arah dan kecepatan, tinggi gelombang baik tinggi gelombang rata-rata maupun tinggi gelombang tertinggi, informasi badai tropis dan jarak pandang.

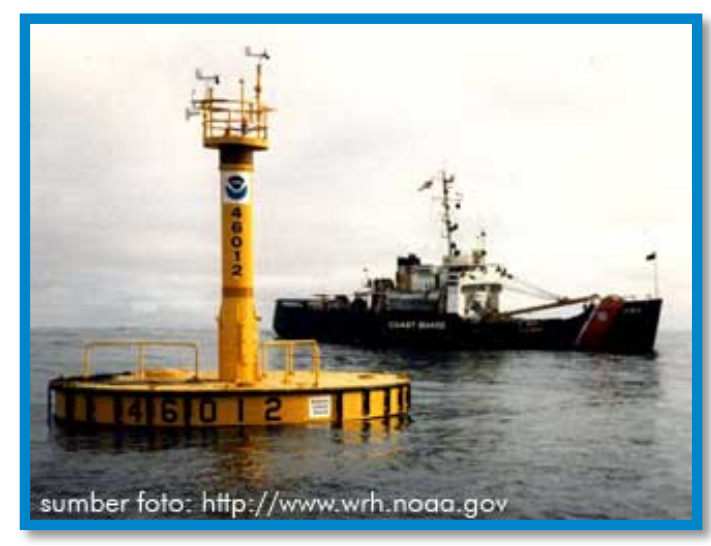

Alat pengukur cuaca di laut.

Cuaca buruk sangat ditakuti di dunia pelayaran karena akibatnya yang menimbulkan berbagai kecelakaan di tengah laut seperti kapal karam atau terdampar yang akhirnya akan menimbulkan banyak korban jiwa. Cuaca buruk di dunia pelayaran antara lain angin kencang, gelombang tinggi, dan storm surge. 


\section{Penyebab cuaca buruk.}

\section{Kecepatan Angin.}

Kecepatan angin sangat berdampak pada pelayaran, kecepatan angin dalam pelayaran di bagi atas :

a. Angin kencang

b. Storm Surge

\section{Tinggi Gelombang}

Merupakan jarak verertical antara puncak dan lembah gelombang. Kriteria tinggi gelombang yang mempengaruhi pelayaran adalah sebagai berikut :

- $1.25-2.0 \mathrm{~m}$ : berbahaya bagi perahu nelayan.

- $2.0-3.0 \mathrm{~m}$ : berbahaya bagi perahu nelayan dan tongkang

- $3.0-4.0 \mathrm{~m}$ : berbahaya bagi perahu nelayan, tongkang dan ferry

- $\quad>4.0 \mathrm{~m}$ : berbahaya bagi semua kapal

\section{Perancangan WAS}

Rancangan WAS (Weather Automatic station ) pada penelitian ini adalah sebagai berikut :

1. Rancangan WAS di pelabuahan Tulehu dan Pulau Saparua

2. Rancangan Station Penerima Di Kampus Fakultas Teknik Universitas Pattimura.

3. Instalasi sistim penerima dengan Sistim Jaringan Internet Di Kampus.

4. Integrasi penggunaan data hasil penerimaan WAS ke berbagai Web dan Media.

5. Dan Pada tahun Kedua adalah rancang bangun WAS Liang dan WAS Waipirit.

6. Integrasi ke 4 WAS ke station penerima.

Rancangan Station WAS adalah sebagai berikut :

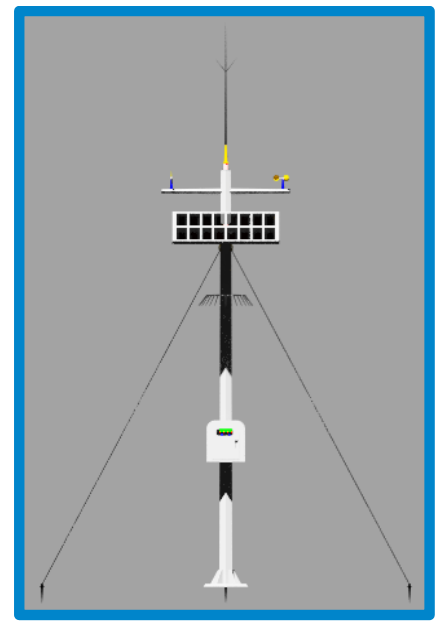

Disain WAS
Pada WAS terdapat peralatan utama sebagai berikut :

1. Tower setinggi 10 Meter dan Kotak Pengaman

2. Antena VHF

3. Sensor Temperatur, kelembaban udara, Anemo meter dan sensor Untuk Curah Hujan.

4. Solar Panel

5. Radio VHF

6. Modem

7. Inverter

8. Converter

9. Batrei Kering

10.Pendingin Udara

Peralatan utama yang terdapat pada Station penerima data WAS di kampus fakultas teknik adalah sebagai berikut :

A. Luar gedung :

1. Tower setinggi 10 Meter diatas gedung kampus

2. Antena VHF

B. Dalam Gedung.

1. PC dengan Software yang terkoneksi internet.

2. Radio VHF

3. Modem

4. Inverter

5. Converter

6. Batrei Kering

7. Pendingin Udara

8. Radio Monitoring.

9. UPS

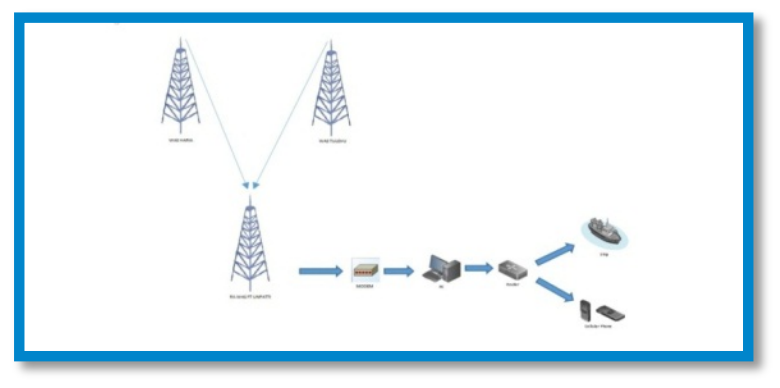

Diagram Blok WAS Penelitian

\section{Metodologi Penelitian}

Pada penelitian ini akan dilaksanakan seperti tergambar pada flowchart berikut : 


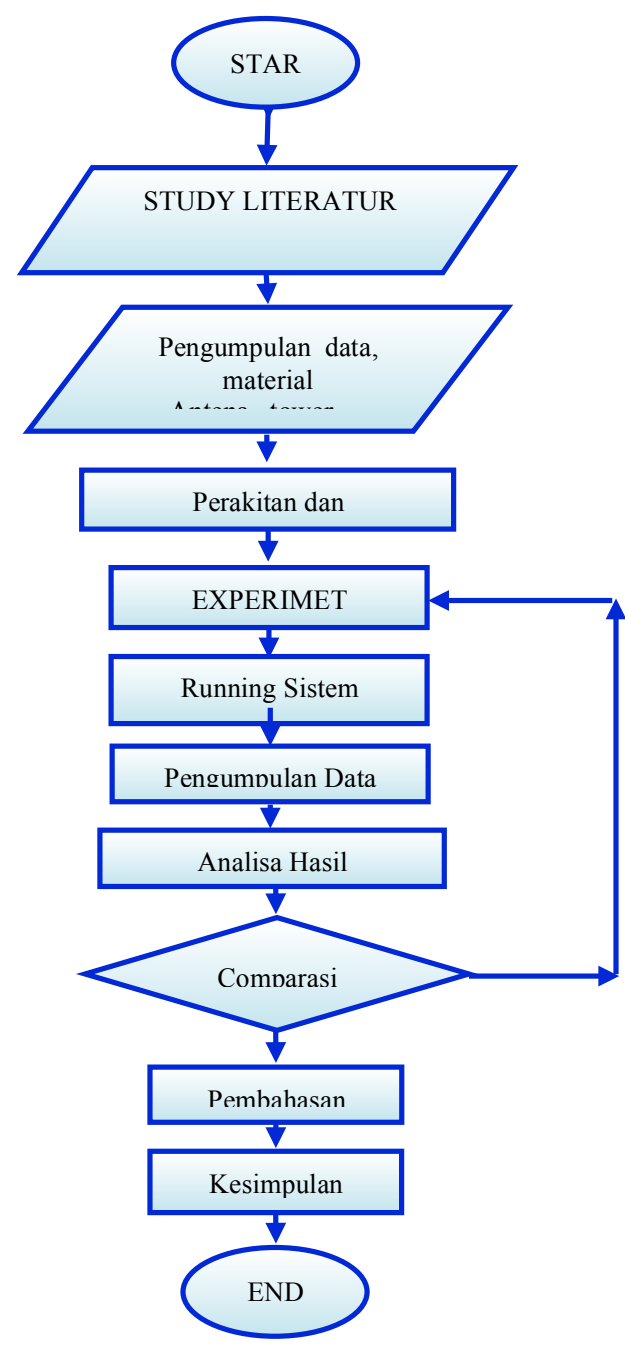

\section{Prosedur Penelitian.}

Penelitian ini di rancang 2 Tahun dengan beberapa Tahapan Pertama diharapkan akan di bangun 2 buah sebuah station cuaca di Daerah Pelabuhan Haria dan Pelabuhan Tulehu, serta Station Penerima yang terletak di Kampus Fakultas Teknik Universitas Pattimura Ambon.

Pada Tahun Pertama saat ini sementara dilakukan pembangunan dan istalasi station Penerima DATA was DI Kampus Fakultas Teknik Unpatti dan WAS di lokasi Pulau Saparua dan pelabuhan tulehu, Methode yang di gunakan adalah sebagai berikut :

Tahap I : Servei Lokasi Peletakan station, dan kebutuhan disain station.

Tahap II Disain Antena dan Disin Tower.

Tahap III Modifikasi radio dan instalasi sistim sensor serta Pemasangan Tower.
Tahap IV Uji Coba penerimaan Sensor dan pengiriman data dari stasion cuaca ke station penerima di Kampus Fakultas Teknik,.

Tahap V Pelaporan

Pada tahun kedua Akan di bangu 2 tambahan yaitu was Pelabuhan Ferry Liang dan Was Pelabuhan Waiprit, dengan demikian cuaca pada lalulintas pelayaran maluku tengah dapat termonitor.

\section{HASIL DAN PEMBAHASAN}

Analisa jarak dan hambatan WAS saparua dan WAS Tulehu ke Staton penerima Di kampus Fakultas Teknik Universitas Pattimura Ambon,pada tahun ke dua hal yang sama dilakukan pada WAS Liang dan WAS Waipirit.
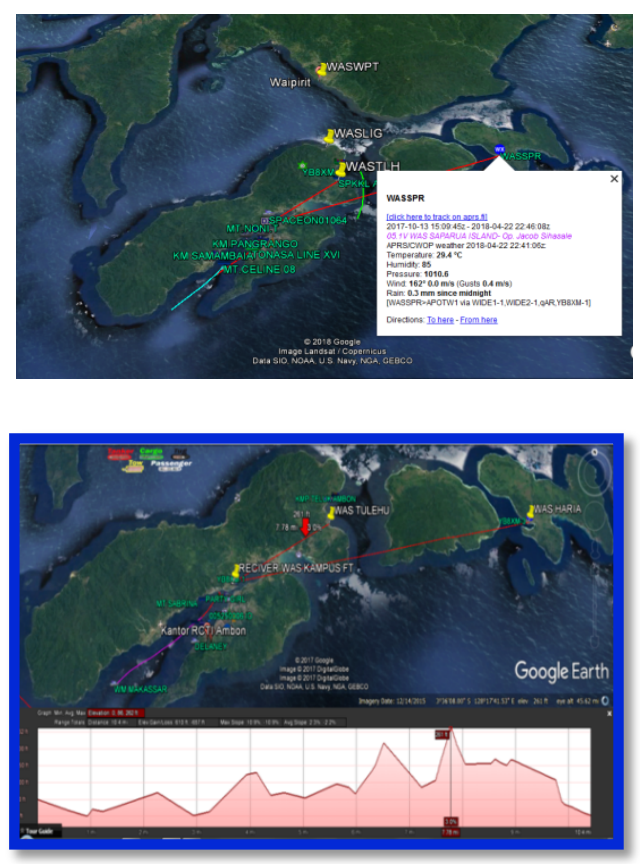

Jarak dan letak Masing masing WAS ke Station Penerima.

Pada saat ini luaran yang telah dicapai adalah :

1. Tersedianya Station Penerima WAS di Kampus Fakultas Teknik Universitas Pattimura.

Staton Penerima Terdiri dari Antena, Radio dan Komputer, diman keseluruhan system beroperasi 24 jam perhari selama 7 hari.

2. WAS Saparua dan WAS Tulehu.

Pada saat ini telah tersedia WAS Saparua dan WAS Tulehu yang telah beroperasi mengirimkan data ke station penerima setiap 5 menit. 
3. Saat ini pengukuran dan pembangunan WAS Liang dan Waipirit sementara di bangun.
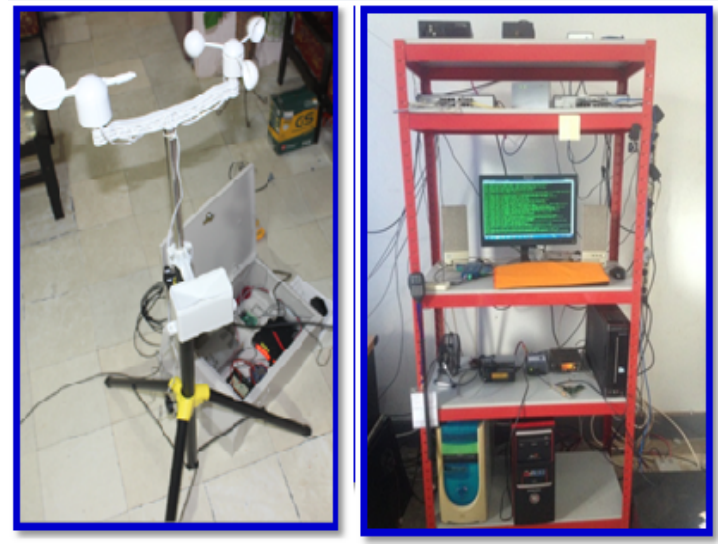

Configurasi WAS dan Station Penerima

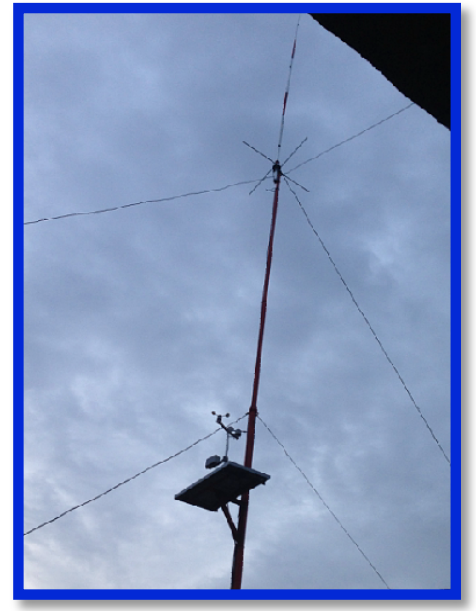

WAS Saparua

Hasil dari WAS yang di pasang dapat di lihat pada web aprs.fi

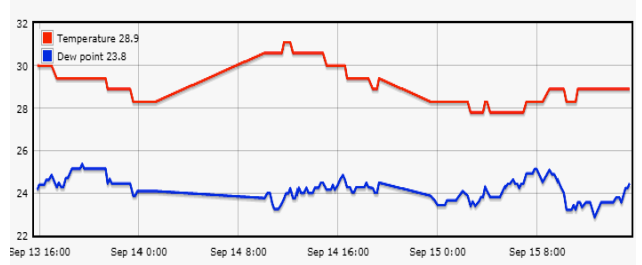

Grafik Temperatur WAS

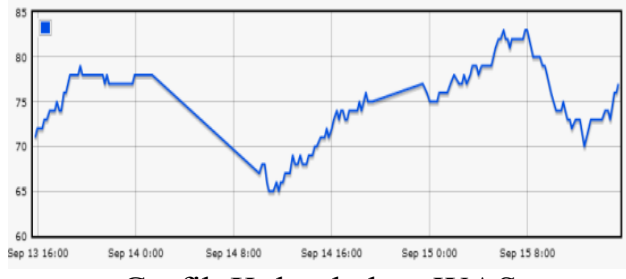

Grafik Kelembaban WAS

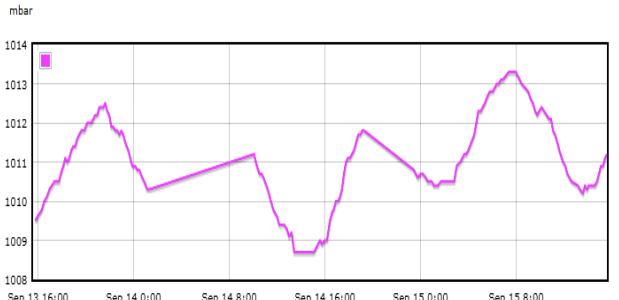

Graik 3. Tekanan WAS Saparua

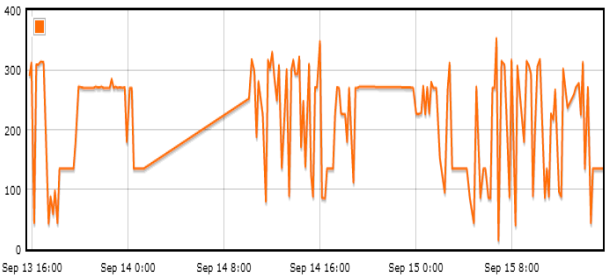

Grafik Arah Angin WAS

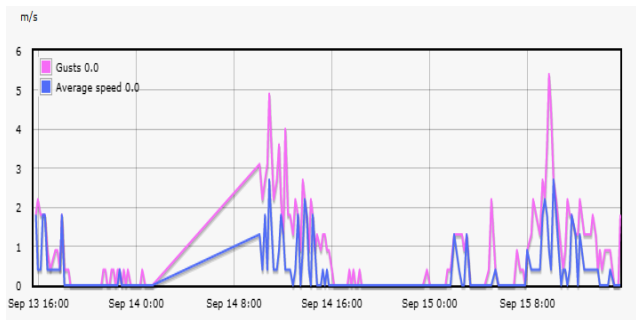

Grafik Kecepatan Angin

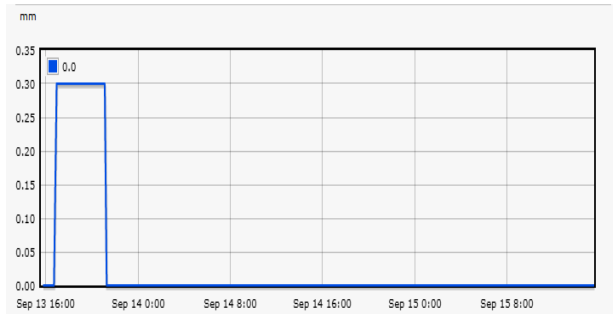

Grafik Curah Hujan

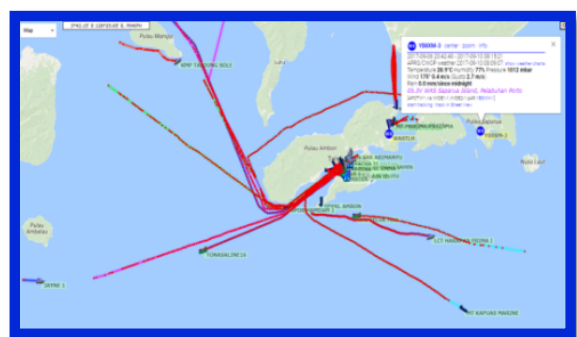

WAS terintegrasi dengan AIS pada aprs.fi

Hasil yang dicapai Telah di lakukannya publikasi tentang penelitian yang di buat pada Seminar Nasional AIPI ( Akademi Ilmu Pengetahuan Indonesia) Komisi Ilmu Rekayasa ( KIR ) Pada 
tanggal 29 -30 Agustus 2017 di Fakultas Teknik Universitas Pattimura Ambon.

Hasil yang di capai juga telah di Publikasi pada web amatir radio https://aprs.fi/\#!addr=AMBON

\section{KESIMPULAN}

Dari pekerjaan Penelitian yang telah dilakukan selama ini di dapatkan beberapa kesimpulan sebagai berikut:

1. Sensor Cuaca dan peralatan utama WAS Saparua dan WAS Tulehu Bekerja Baik.

2. Station Penerima di Kampus Bekerja Baik dan dapat menerima Signal Radio VHF dengan jarak terjauh $50 \mathrm{nM}$, dengan Trasmisi dari Pemancar radio VHF $10 \mathrm{~W}$.

3. Data cuaca yang direkam Dari Station Cuaca WAS Saparua dan Tulehu dapat diterima sempurna di Station Penerima di Kampus Fakultas Teknik Unpatti.

4. WAS Liang dan WAS Waipirirt dalam Pengukuran dan Pekerjaan penyelesaian.

5. Perubahan transmisi data Cuaca dari WAS di kirim ke Station Penerima dengan interfal 300 Detik, Kecepatan Angin 2 MPH, Dan dengan perubahan Arah Angin 10 Derajat, yang kemudian dapat di shearing ke berbagai web yang berhubungan dengan Weather.

6. Para calon penumpang dan - penyelenggara Pelayaran serta para nelayan dan petani datap mengakses data cuaca pada dua lokasi berbeda pada berbagai device.

7. Dengan Masyarakat mengetahui akan Kondisi Cuaca pada daerah pelayaran tersebut maka kecelakanan laut dan korban dapat di kurangi

\section{DAFTAR PUSTAKA}

Ahmad Zatnika Purwalaksana, 2015 otomatisasi transfer data pengamatan automatic weather station (aws) serta pemanfaatannya dalam satellite disaster early warning system (sadewa)

Australian Government - Bureau of Meteorology, "Automatic weather stations for agricultural and other applications", (1995) (Updated 2005).

Automatic Weather Stations Project. Antarctic Automatic Weather Stations Project. Retrieved on 2008-06-11.

ARLL HAND BOOK 2014, The National Association for Amateur Radio.

C. Liu, H. Lee, J. Yang, J. Huang, Y. Fang, B. Lee and C. King, "Development of a long- lived, real-time automatic weather station based on WSN", In Proceedings of SenSys 2008, (2008), pp. 401-402.

Cambridge University Press 978-1-107-02681-0 The Weather Observer's Handbook Stephen Burt

da Costa, Jose S, P., Sarmento, A., Gardner, F. "Modeling of an ocean waves power device AWS" Proceedings of 2003 IEEE Conference on Control Applications, Vol.1, PP. 618-603, 23-25 June, 2013.

D.Bambang Setiono Adi , Noutika kapal penangkap ikan.

Dandan Hendayana,SP, Mengenal Nama dan Fungsi Alat-alat Pemantau Cuaca dan Iklim,

Electrical and Electronics Engineering: An International Journal (ELELIJ) Vol 2, No 4, November 2013

IMO 2014

Lynn Hope Philip, Cornell University, 1972, An automatic weather station for agriculture and climatology.

Peraturan menteri perhubungan nomor : 7 tahun 2005 tentang penyelenggaraan sarana bantu navigasi pelayaran.

R W Munro Limited,Monitoring the world around us since 1864,Automatic weather stations.

Rini Nuraeni, M.Si .IKLIM DAN CUACA 2009

Xingang Guo, Yu Song "Design of automatic weather station based on GSM module" International Conference on Computer, Mechatronics, Control and Electronic Engineering (CMCE), Vol.5, PP. 80-82, August 24-26, 2010.

$\mathrm{X}$. Guo and Y. Song, "Design of automatic weather station based on GSM module", 2010 International Conference on Computer, Mechatronics, Control and Electronic Engineering (CMCE), vol. 5, (2010) August 24-26, pp. 80-82. 